\title{
Towards a greenhouse treaty?
}

Last week's meeting of the Intergovernmental Panel on Climate Change at Stockholm seems to have done a useful job, the disappointments of some of its well-wishers notwithstanding.

MANY of the most interested observers, especially the environmentalist pressure groups, were disappointed by what they heard and saw at last week's meeting of the International Panel on Climate Change (IPCC) at Stockholm, but that was inevitable. Some had gone expecting a firm prescription of future emission limits for greenhouse gases, but found instead merely a revision of three documents in circulation since the early summer, some of which appeared to have been watered down. But it could not have been otherwise. IPCC is not an international authority empowered to issue global edicts, but an advisory committee. Its immediate function is to prepare a technical report for an intergovernmental conference arranged by the United Nations at Geneva in November. That conference will be asked to decide whether there should be an international convention on greenhouse gases. IPCC's report should be influential, but not decisively so; much more will hang on the inclinations of the participating governments. There is no other mechanism for making international law.

To the extent that some disappointment stems from the greater emphasis in the latest version of IPCC's report on the uncertainties in the greenhouse calculations, it is entirely misplaced. For there are uncertainties, not merely imprecisions of calculation but uncertainties about the physics of the problem. What is the fate of oceanic carbon and the effect of real clouds on ground-level insolation, for example? If IPCC were to make light of these conundrums, its report would be more open to just criticism and thus less persuasive of the doubters. There is even something in the view that governments fearful that the whole greenhouse rumpus is a device for meddling in their economic affairs will be more tempted to negotiate seriously if they are told there may be a problem - not that there is a problem.

That is why the best hope for November is that governments will agree to begin negotiating a convention on greenhouse gases. How should they do that? The first task is to produce a working list of topics to be covered by a convention. IPCC now includes a reference to the need for monitoring emissions, but not every participant in November will agree. And should there be penalties for proven transgressions? Should there be a procedure for amending the convention, and how will that be done? Who will decide how the damage done by different greenhouse gases should be balanced? Should the poor coun- tries of the world be compensated for compliance, and if so how, and on what scale? What balance will there be between adaptation to climate change and its avoidance? And how (or by whom) will that be decided?

Even the core clause of a convention - an undertaking by the signatories that, from a certain date, they will hold emissions of greenhouse gases to prescribed amounts leaves ample room for argument. Should limits be related to present emissions (thus penalizing developing countries) or to Gross Domestic Product (GDP, thus penalizing both poor countries and inefficient energy-users)? There would be merit in emission limits related to GDP per head of population, for then most poor countries would for some time be unconstrained while large but inefficient energy consumers would be tightly squeezed, but such a scheme would provoke cries that rapid population growth is a way of busting the convention.

The last difficulty shows that the greenhouse problem is not an isolated problem - one that can be 'solved' in isolation. Its links with the international monetary problem are even stronger. And while lists of questions yet to be answered may suggest that the negotiation of a treaty is an insuperable task, the truth is that they (and other questions) will have to be answered before a convention will stick. That is why there is a need to begin negotiations now, however woolly the draft treaty may be. IPCC's uncertainties will be mostly cleared up long before a convention is in place.

Completing them will be a long and difficult task unlikely to be finished this century. Many of IPCC's doubts should have been cleared up by then, even if others replace them. What the enthusiasts for a convention should grasp is that their goal will require of its signatories an unprecedented degree of self-denial.

\section{Remote research}

New Zealand should battle imaginatively against the illluck of malevolent geography.

How should a small country make sensible policies for research and higher education? There are models of success, such as Switzerland and the Benelux countries, and of indifference, such as Ireland. New Zealand, by general consent one of the most delectable places on the 